\title{
9.2 Дослідження функції кооперативної реклами у вертикальному каналі виробника та роздрібного продавця
}

Розподіл витрат реклами між виробником і дилером (кооперативна реклама) грає істотну роль маркетингових програмах i умовних системах ланцюжка (постачання) поставок. А також, поділяє більшу частину асигнувань (сума грошових коштів, виділена 3 централізованих або децентралізованих джерел фінансування для покриття витрат на певні цілі) на рекламну діяльність у багатьох виробничих лініях, як і для фірм - виробників, так і для підприємств роздрібної торгівлі. Однак, на даний момент більшість досліджень 3 кооперованої реклами припускають, що потреба ринку знаходиться лише під впливом рекламного рівня, але в жодному разі не роздрібної ціни.

Відмітимо, що вертикальна кооперована реклама - це скоординоване зусилля всіх членів каналу розподілу збільшення споживчого попиту та загального прибутку. У типовому каналі розподілу орган висхідного потоку даних може бути виробником певного продукту, який часто просуває свій продукт через рекламу національного рівня, щоб побудувати тривале зображення або "пізнаваність бренду" компанії. Тим часом, орган низхідного каналу може бути підприємством роздрібної торгівлі, яке зазвичай рекламує продукт на його локальному (місцевому) ринку, щоб викликати короткострокову покупку. Зазвичай, кооперована реклама успішно виконана фірмою-виробником висхідного потоку даних, що спільно використовує частину витрат на рекламу для підприємства роздрібної торгівлі основного напряму, як правило, спрямованого і як частка робочої сили в загальній чисельності цієї цільової групи фірми - виробника (Bergen \& John, 1997) . Кооперативна реклама часто використовується в промисловості споживчих товарів та відіграє істотну роль у ринковій стратегії для багатьох компаній. Згідно з Nagler (2006), загальна американська витрата кооперованої реклами в 2000 була планована в 15 млрд \$, майже чотириразове збільшення в незмінних цінах порівняно з 900 мільйонами \$ в 1970 . Huang та Li $(2001,2002)$ є двома науковими працямии з корпоративної 
реклами, де три рекламні моделі представлені одним періодом. Вони досліджували роль вертикальної кооперативної реклами та іiі ефективність у відношенні до транзакцій між виробником та роздрібним продавцем через фірмові інвестиції, витрати локальної реклами та спільне використання правил витрат на рекламу.

Динамічні завдання кооперованої реклами також предсталені, наприклад, Chintagunta and Jain (1992); Jorgensen, Zaccour, and Sigue (2000); Jorgensen, Tiboubi, i Zaccour (2003) та іншими дослідниками. У сучасних ринкових умовах питання формування та оцінки рекламних витрат в системі маркетингу підприємства визначає пошук оптимальних моделей та їх «налаштування» на конкретну ситуацію.

Розглядається економіко-математичне моделювання рекламних витрат та функція кооперативного прибутку сумісної взаємодії підприємств виробника та ритейлера. Зображено поверхні розв’язку визначення рекламних витрат при різних значеннях змінних системи визначення прибутку.

Розглянемо функцію реакції рекламних асигнувань $\varphi(a, q)$ від двох змінних: $q$ - витрат на національну рекламу виробником продукції, $a$ - рівня рекламних витрат роздрібного продавця.

Функція $\varphi(a, q)$ була запропонована у 2001 р. Ханг та Лі у вигляді:

$$
\varphi(a, q)=A-\frac{B}{a^{\gamma} q^{\delta}}, \quad A, B>0, \quad a, q>0, \quad \gamma+\delta=1
$$

Функція $\varphi(a, q), a, q \in R$ має вигляд поверхонь, зображених за різних умов параметрів (таблиця 1), що обчислювалися у он-лайн калькуляторі: https://www.wolframalpha.com/input/?i=plot3D\%5B2++3\%2F\%28\%D1\%85\%5E0.2*y\%5E0.8\%29\%2C\%7Bx\%2C-10\%2C55\%7D\%2C\%7By\%2C-20\%2C50\%7D\%5D 


\section{Таблиця 1}

\section{Дослідження поверхні кооперативної реклами.}

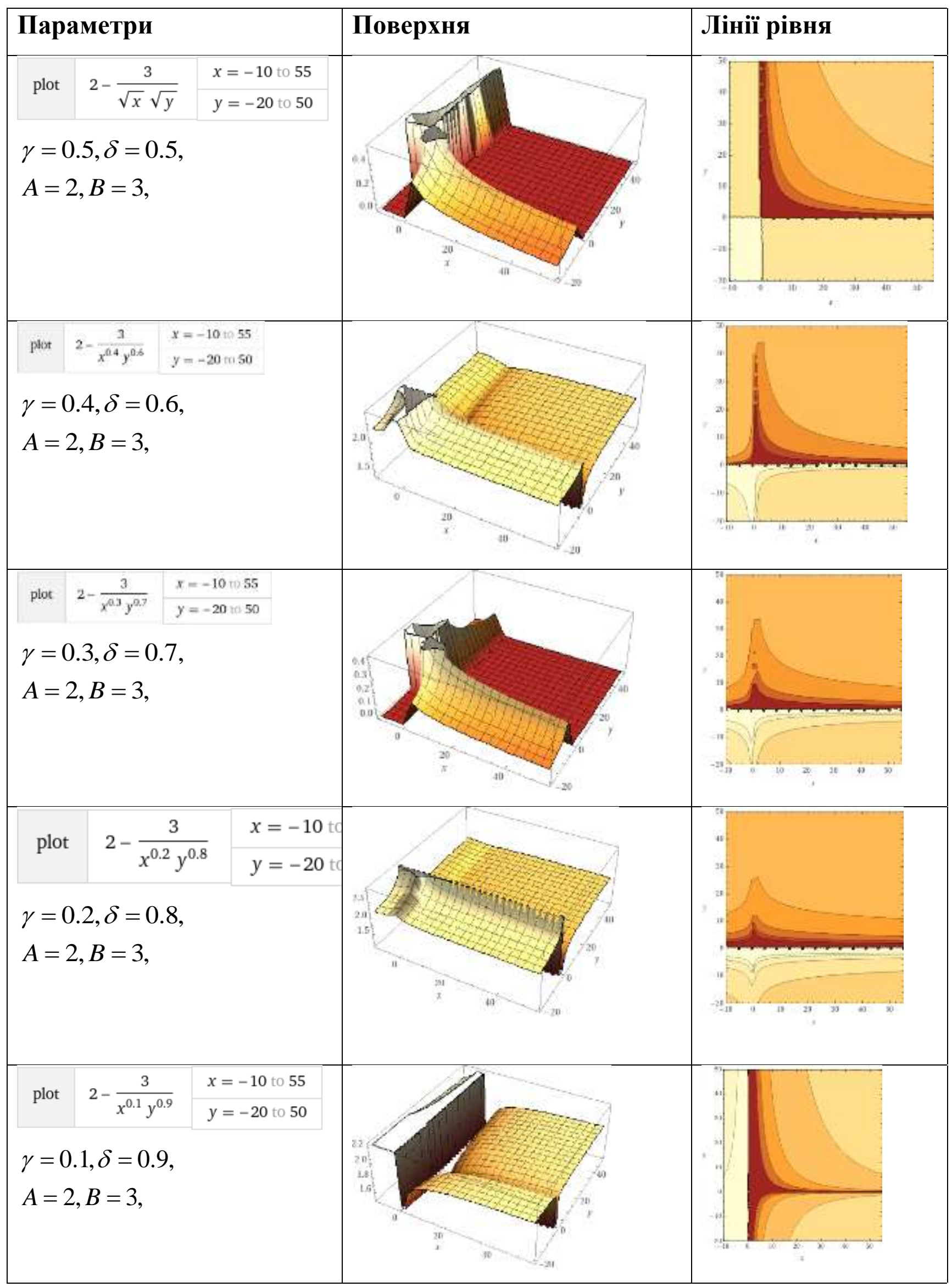


Розглянемо двосторонній ланцюжок поставок, де один виробник продає товар оптом одному роздрібному продавцю, який продає товар виробника споживачам. Отже, розглянемо прибуток сумісної взаємодії підприємствавиробника та підприємства роздрібної торгівлі, або цей прибуток можна назвати функцією кооперативного прибутку, що залежить від трьох змінних: $D=D\left(x_{R}, a, q\right)$.

Знайдемо:

$\max _{x_{R}, a, q} D\left(x_{R}, a, q\right)=\max _{x_{R}, a, q}\left[x_{R}\left(1-x_{R}\right)\left(\frac{A}{B^{\frac{1}{\gamma+\delta+1}}}-\frac{1}{a^{\gamma} q^{\delta}}\right)-a-q\right]$.

де $x_{R}$ - ціна одиниці продукції продавця, $a$ - рівень рекламних витрат продавця, $q$ - витрати на національну рекламу виробником продукції, $\alpha, \beta \in R$, $A, B>0, a, q>0, \quad \gamma+\delta=1$.

Запишемо необхідні умови екстремуму функції кооперативного прибутку (візьмемо частинні похідні по кожній змінній та прирівняємо їх до нуля):

$$
\left\{\begin{array}{l}
\frac{\partial D}{\partial x_{R}}=\left(1-2 x_{R}\right) \cdot\left(\frac{A}{B^{\frac{1}{\gamma+\delta+1}}}-\frac{1}{a^{\gamma} q^{\delta}}\right)=0, \\
\frac{\partial D}{\partial a}=\gamma \cdot x_{R} \cdot\left(1-x_{R}\right) \cdot a^{-(\gamma+1)} \cdot q^{-\delta}-1=0, \\
\frac{\partial D}{\partial q}=\delta \cdot x_{R} \cdot\left(1-x_{R}\right) \cdot a^{-\gamma} \cdot q^{-(\delta+1)}-1=0 .
\end{array} .\right.
$$

3 першого рівняння системи (3) знаходимо:

$$
\left(1-2 x_{R}\right)=0 \quad \Rightarrow \quad x_{R}=\frac{1}{2} \text {. }
$$

3 другого та третього рівняння системи (3) одержимо:

$$
\gamma \cdot x_{R} \cdot\left(1-x_{R}\right) \cdot a^{-(\gamma+1)} \cdot q^{-\delta}=\delta \cdot x_{R} \cdot\left(1-x_{R}\right) \cdot a^{-\gamma} \cdot q^{-(\delta+1)} .
$$

Звідси маємо: 


$$
\gamma \cdot q=\delta \cdot a \quad \Rightarrow \quad q=\frac{\delta}{\gamma} \cdot a
$$

Підставляючи значення $q$ в третє рівняння системи (3), маємо:

$$
\frac{1}{4} \delta \cdot a^{-\gamma} \cdot\left(\frac{\delta}{\gamma} a\right)^{-(\delta+1)}=1,
$$

або

$$
\frac{1}{4} \delta \cdot\left(\frac{\gamma}{\delta}\right) \cdot a^{-(\delta+\gamma+1)} \cdot\left(\frac{\delta}{\gamma}\right)^{-\delta}=1, \quad \Rightarrow \quad a^{(\delta+\gamma+1)}=\frac{\gamma}{4} \cdot\left(\frac{\delta}{\gamma}\right)^{-\delta} .
$$

Звідси знаходимо:

$$
a=\left[\frac{\gamma}{4} \cdot\left(\frac{\gamma}{\delta}\right)^{\delta}\right]^{\frac{1}{(\delta+\gamma+1)}} .
$$

Таким чином отримуємо розв'язки для максимального значення функції кооперативного прибутку у вигляді:

$$
\left[\begin{array}{c}
x_{R}=\frac{1}{2} \\
a(\gamma, \delta)=\left[\frac{\gamma}{4} \cdot\left(\frac{\gamma}{\delta}\right)^{\delta}\right]^{\frac{1}{(\delta+\gamma+1)}}, \\
q(\gamma, \delta)=\frac{\delta}{\gamma} \cdot a(\gamma, \delta) \Rightarrow q(\gamma, \delta)=\delta^{1-\frac{\delta}{(\delta+\gamma+1)}} \cdot \gamma^{\frac{1+\delta}{(\delta+\gamma+1)}-1}
\end{array}\right.
$$

Прибутки виробника та роздрібного продавця залежать від ціни та рівня відрахувань на спільну (кооперативну) рекламу. Припускається, що більш точно максимізувати індивідуальний прибуток і для виробника, i для ритейлера, буде складніше, ніж у випадку системного співробітництва.

На рис.1, 2 зображено поверхні витрат на національну рекламу виробником продукції $a(\gamma, \delta)$ та поверхні рівня рекламних витрат продавця $(\gamma, \delta)$ при різних значеннях змінних. 


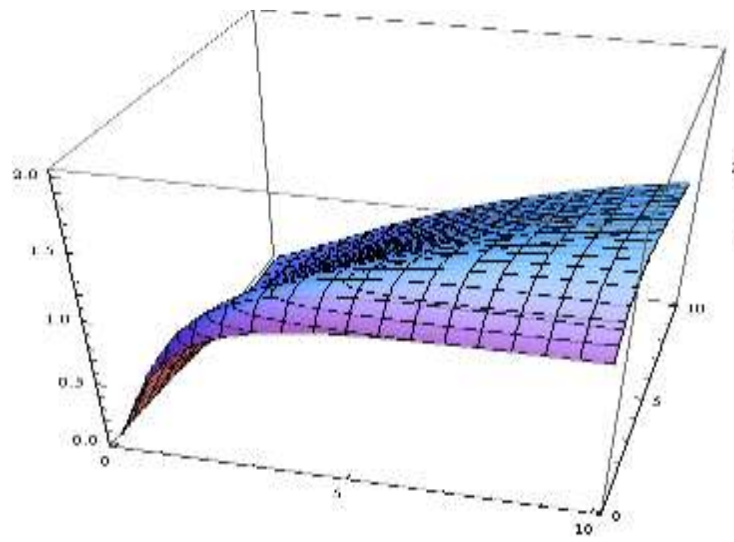

a)

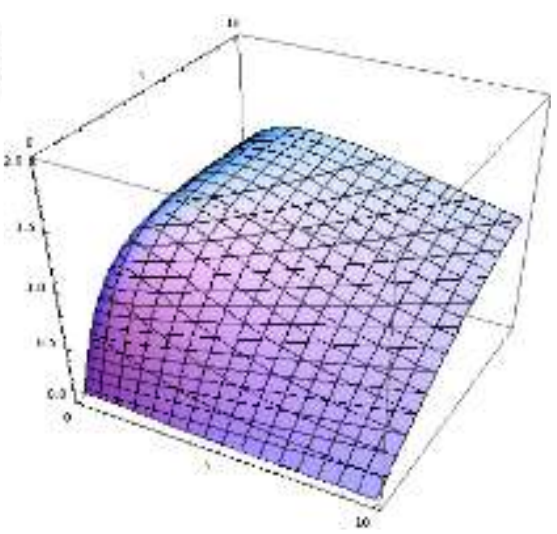

б)

Рис.1. Поверхня витрат на національну рекламу виробником продукції $a(\gamma, \delta)$ (а) та поверхня рівня рекламних витрат продавця $(\gamma, \delta)($ б). при

$$
\gamma \in[0.1 ; 10], \delta \in[0.1 ; 10], a \in[0.01 ; 10]
$$

Мотивуючою ціллю виробника є отримання додаткового прибутку, а також послідуючий механізм розподілення даного прибутку, який виробник та ритейлер досягають рухаючись до співпраці. Для виробника вибір узгодженої, координованої програми, навіть у випадку диктованих умов роздрібного продавця, завжди кращий, ніж ситуація конфлікту. Результати додаткових статистичних досліджень надають можливість оцінити конкурентні позиції та якість співробітництва через оптимізацію політики ціноутворення та кооперативну рекламну компанію між учасниками взаємодії.

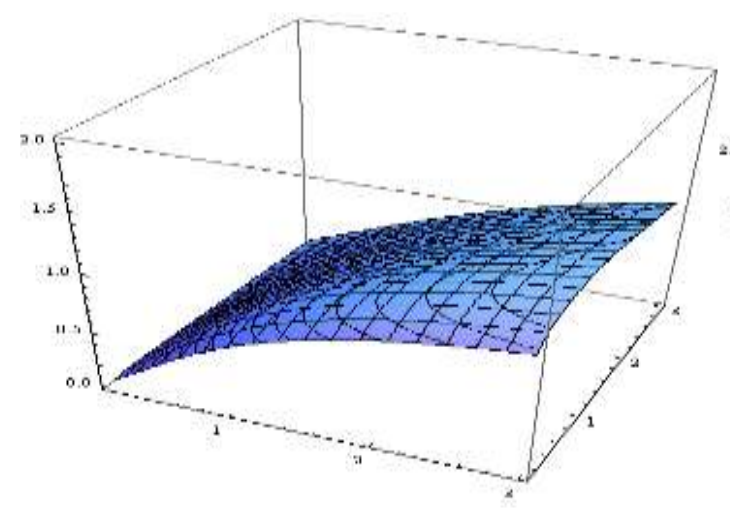

a)

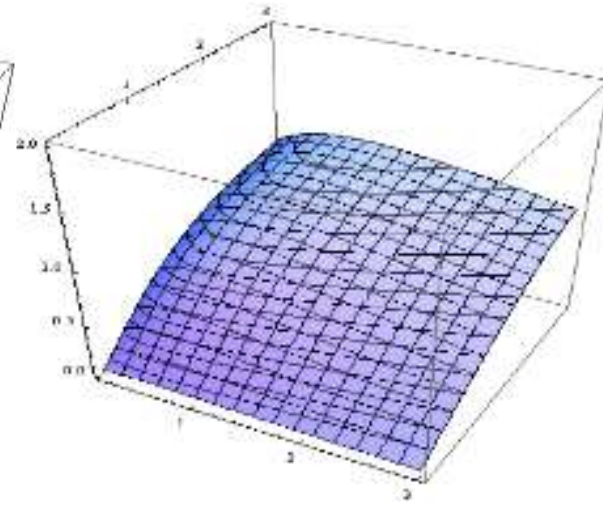

б)

Рис.2. Поверхня витрат на національну рекламу виробником продукцї $a(\gamma, \delta)$ (а) та поверхня рівня рекламних витрат продавця $(\gamma, \delta)$ (б) при

$$
\gamma \in[0.1 ; 3], \delta \in[0.1 ; 3], a \in[0.01 ; 2]
$$


Таким чином, аналіз моделювання функцій витрат на рекламну кампанію умовного клас - продукту відкриває можливість інтегрувати спільну політику його просування на динамічному конкурентному ринку. Розрахунок визначення та встановлення оптимальної оптової та роздрібної ціни; закріплення конкурентоздатних позицій продукту за рахунок його рекламування, дає можливість збільшення збуту виробленого продукту для виробника та збільшення прибутку для дилера, - що може бути мотивом для формування довгострокових партнерських відносин між виробником та роздрібним продавцем.

У сучасних умовах для успішного функціонування будь-яких підприємств вже недостатньо використовувати класичний трансакційний маркетинг. Пріоритетним напрямком розвитку підприємства стає підтримка довгострокових, надійних зв'язків з бізнес-партнерами, формування кола лояльних споживачів та формування маркетингу відносин [473].

Певної значущості та актуальності набуває моделювання побудови пріоритетних напрямків розвитку якісних стосунків у вертикальних каналах постачання. Для досягнення ефективної взаємодії між двома сторонами необхідно розуміння переваг, які будуть отримані в результаті 